\title{
Sprawozdanie z VIII Ogólnopolskiej Interdyscyplinarnej Konferencji Naukowej Język religijny dawniej i dziś (w kontekście teologicznym i kulturowym)
}

\author{
Marta Wrześniewska-Pietrzak \\ Wydział Filologii Polskiej i Klasycznej, Uniwersytet im. Adama Mickiewicza w Poznaniu, \\ ul. Fredry 10, 61-701 Poznań, Polska; \\ e-mail: martaw-p@amu.edu.pl
}

W dniach 22-24 września 2016 roku w Poznaniu odbyła się ósma międzynarodowa i interdyscyplinarna konferencja naukowa z cyklu Język religijny dawniej i dziś (w kontekście teologicznym i kulturowym). Konferencja organizowana była przez Zakład Gramatyki Współczesnego Języka Polskiego i Onomastyki IFP Uniwersytetu im. Adama Mickiewicza w Poznaniu, Zespół Języka Religijnego Rady Języka Polskiego przy Prezydium Polskiej Akademii Nauk oraz Komisję Języka Religijnego Międzynarodowego Komitetu Slawistów i Komisję Językoznawczą PTPN. Wzięło w niej udział pięćdziesięciu prelegentów reprezentujących różne ośrodki akademickie w Polsce (Uniwersytet Jagielloński, Polska Akademia Umiejętności w Krakowie, Uniwersytet Szczeciński, Uniwersytet Kazimierza Wielkiego w Bydgoszczy, Uniwersytet Zielonogórski, Uniwersytet Śląski w Katowicach, Katolicki Uniwersytet Lubelski Jana Pawła II, Uniwersytet Mikołaja Kopernika w Toruniu, Uniwersytet Warszawski, Uniwersytet Łódzki, Akademia im. Jana Długosza w Częstochowie, Uniwersytet Pedagogiczny im. KEN w Krakowie, Politechnika Opolska, Uniwersytet im. Adama Mickiewicza w Poznaniu), a także zagranicą: University of West Bohemia in Pilsen, Uniwersytet Mateja Bela w Bańskiej Bystrzycy (Słowacja), Akademische Verlagsoffizin Bauer \& Raspe w Insingen (Niemcy).

Temat przewodni tegorocznego spotkania związany był z 1050. rocznicą chrztu Polski. Stał się on zagadnieniem centralnym kilku wystąpień, w których prelegenci starali się przedstawić zarówno początki i drogi polskiego chrześcijaństwa, wskazać rolę chrztu Polski w historii języka polskiego (prof. dr hab. Bogdan Walczak, prof. dr hab. Leszek Bednarczuk), historie biblijne jako klucz do rozumienia chrztu u Ojców Kościoła (mgr lic. Zbigniew Barciński), jak i sposoby przedstawiania 1050. rocznicy chrztu Polski w przekazach radiowych (dr Katarzyna Zagórska) czy w tzw. dyskursie rocznicowym (prof. dr hab. Joanna Sobczykowa). Niezwykle ciekawe spojrzenie na tytułowe zagadnienie tegorocznego 
spotkania naukowego odzwierciedlały teksty, w których autorzy ukazywali zależności między polszczyzną biblijną a literacką (prof. dr hab. Stanisław Koziara). Ponadto dwa teksty odnosiły się do obrządku chrztu świętego obecnego w kulturze innej niż polska (PhDr. Michaela Laštovičková Ph.D., PhDr. Marcela Grygerková Ph.D.; dr hab. Gabriela Olchowa).

Zgodnie z konwencją przyjętą podczas cyklicznych konferencji Język religijny dawniej i dziś część wystąpień odnosiła się do problematyki szeroko rozumianego języka religijnego.

Zgłoszone referaty pozwoliły wyróżnić kilka kręgów tematycznych: problem sacrum w literaturze, słownictwo religijne w różnych tekstach kultury, język liturgii i kazań, język religijny w przekładzie, semiotyczna analiza symboli o proweniencji religijnej, język religijny $\mathrm{w}$ filmie, obrazowość języka religijnego a audiodeskrypcja.

Dwa wystąpienia dotyczyły postaci papieża Franciszka. Ks. prof. dr hab. Wiesław Przyczyna i dr Aneta Załazińska przedstawili jego wizerunek kreowany przez polskie, katolickie portale internetowe, natomiast dr hab. Elżbieta Kucharska-Dreiß scharakteryzowała pierwszy ilustrowany magazyn o papieżu Franciszku.

Materiał prasowy z pierwszej połowy 1966 roku wybrany do analizy przez dr hab. Katarzynę Czarnecką stał się podstawą do zbadania obecnego w nich obrazu Kościoła.

Podobnie jak większość dotychczasowych spotkań konferencyjnych, tak i tego roku spora część referentów swoją uwagę skupiła na analizie wybranych leksemów i pojęć religijnych w tekstach Karola Wojtyły/Jana Pawła II (m.in. dr hab. Małgorzata Rybka i dr Marta Wrześniewska-Pietrzak przedstawiły językowy obraz matki w pismach papieża-Polaka, a dr Jolanta Sławek zwróciła uwagę na semantykę wody, która w poezji Karola Wojtyły/ Jana Pawła II stanowi przestrzeń uobecniającą sacrum).

Część referatów dotyczyła kwestii literackich. Prof. dr hab. Jacek Baluch przedstawił uczestnikom relacje między rolami: filologa, teologa-biblisty i osoby określanej mianem poeta doctus. Z kolei prof. UAM dr hab. Leszek Teusz zwrócił uwagę na kwestie biblijnych znaków świadomości egzystencjalnej polskich poetów barokowych. Prof. UŚ dr hab. Bożena Mazurkowa, analizując poezję Franciszka Dionizego Kniaźnina, wskazała religijne konteksty metaforyki żywiołów w twórczości poety.

Część wystąpień poświęcona była też terminologii religijnej występującej w słownikach dawnych i współczesnych. Prof. UKW dr hab. Mirosława Wronkowska-Dimitrowa omówiła obecność terminologii religijnej w cerkiewnosłowiańsko-polskim słowniku z 1722 roku. Natomiast dr hab. Jolanta Migdał wskazała wyniki dotyczące badań nad szesnastowiecznym słownictwem religijnym. Prof. dr hab. Andrzej Sieradzki na podstawie analizy słownikowej omówił występowanie teonimu Perun w leksyce średnio- i nowopolskiej. Z kolei funkcjonowanie leksyki religijnej we współczesnych słownikach języka polskiego przedstawiła dr Agnieszka Piotrowska-Wojaczyk. 
Analiza tekstów dawnych pod kątem leksyki religijnej stanowiła przedmiot badania mgr s. Małgorzaty Wojtaszek, która na podstawie dokumentów Zgromadzenia Sióstr Opatrzności Bożej omówiła zapomniane wyrazy i związki wyrazowe z kręgu leksyki religijnej. Dr Ewa Zmuda natomiast analizowała połączenia wyrazowe z przymiotnikiem duchow(n)y w XVII-wiecznych rękopisach zakonnic. Słuchacze mogli też zapoznać się ze studium leksykalnym śmierci na podstawie analizy żywotów świętych pieczarskich, które przedstawiła dr hab. Jolanta Klimek-Grądzka.

W kilku wystąpieniach prelegenci analizowali też język kazań, nabożeństw i liturgii. Dr Renata Bizior zwróciła uwagę na często obecny w dzisiejszym dyskursie nie tylko religijnym stereotyp Polaka-katolika, a na podstawie kazań z 2. połowy XIX wieku referentka omówiła jego relacje względem Innego obecne we wspólnotowym obrazie świata. Z kolei dr Agnieszka Sieradzka-Mruk porównała eksklamacje obecne w dawnych i współczesnych tekstach nabożeństwa drogi krzyżowej. Dr Wiktor Pskit natomiast przedstawił angielską wersję Mszału Pawła VI.

Podczas VIII konferencji z cyklu Język religijny dawniej $i$ dziś obecne też były wystąpienia dotyczące tłumaczeń tekstów religijnych. Problemy przekładu związane $\mathrm{z}$ katolickim nauczaniem w prawosławnej szacie językowej przedstawiła prof. dr hab. Viara Maldjieva. Kwestię przekładu przypowieści o synu marnotrawnym w aspekcie teologii miłosierdzia omówił ks. dr hab. Andrzej Draguła. Natomiast dr Dorota Rojszczak-Robińska swoją uwagę skupiła na trudnościach wynikających $\mathrm{z}$ tłumaczenia psalmów w staropolskich apokryfach pasyjnych. $\mathrm{Z}$ kolei mgr Dorota Masłej przedstawiła zapomniane polskie thumaczenia tzw. Parafrazy Modlitwy Pańskiej Ludolfa z Saksonii.

Niezwykle ciekawe były także wystąpienia, w których pojęcie języka - zgodnie z przyjętą formułą konferencji - rozumiane było szeroko, odnosiło się bowiem do sztuk wizualnych lub komunikacji niewerbalnej. Dr Małgorzata Haładewicz-Grzelak na podstawie analizy ikonografii świętego Mikołaja zaprezentowała tezę dotyczącą semiotyzacji stanowiącej proces kulturowy. Natomiast dr Beata Drabik przyjrzała się gestom liturgicznym i przedstawiła ich postrzeganie zarówno przez językoznawcę, jak i komunikologa. W obrębie zainteresowania badaczy znalazł się również film. Dr Iwona Grodź w swoim wystąpieniu na temat sacrum w obrazie filmowym przyjrzała się dziełom Jerzego Kawalerowicza i zwróciła uwagę na kwestię języka filmu, jak i języka w filmie. Natomiast mgr Beata Jerzakowska, omawiając kwestię audiodeskrypcji obrazów religijnych, zwróciła uwagę na kwestie wykorzystywania ekfrazy poetyckiej.

Ubiegłoroczną konferencję uświetnił wieczór autorski ks. Grzegorza Stachury zatytułowany Niedożegnani w błękicie zzieleniałym, który poprowadził ks. dr hab. Stefan Radziszewski. Uczestnicy konferencji mogli zapoznać się z wybranymi utworami poetyckimi ks. Stachury, które przedstawiane były chronologicznie, dzięki czemu uwydatniły się dominanty twórczości charakterystyczne dla poszczególnych okresów twórczości (tomików poety). Całość spotkania uświetniły występy słowno-muzyczne młodzieży z Poznańskiej Szkoły Chóralnej Jerzego 
Kurczewskiego i VIII Liceum Ogólnokształcącego im. Adama Mickiewicza w Poznaniu.

Ósme spotkanie naukowe z cyklu Język religijny dawniej i dziś (w kontekście teologicznym $i$ kulturowym) potwierdziło, że badania nad językiem religijnym dotyczą różnych zagadnień, obejmują problematykę historyczną, a także współczesną. Różnorodność podejmowanych tematów z pewnością może być uznana za atut tej naukowej konferencji, zachęcała bowiem do dyskusji, w których interdyscyplinarność, a także różnorodność metodologiczna pozwalały uczestnikom poznać różne możliwości interpretacyjne, nierzadko oświetlające wybrane zagadnienia $\mathrm{z}$ wielu stron. 